Piotr Kołodko

Uniwersytet w Białymstoku e-mail: p.kolodko@uwb.edu.pl telefon: +48 857457162

DOI: $10.15290 / \mathrm{mhi} \cdot 2015.14 .01 .15$

\title{
Kilka uwag na temat rzymskiego prawa karnego w Institutiones Marcianusa
}

\section{SUMMARY}

\section{A Few Remarks on the Roman Criminal Law in Marcian's Institutions}

The text presents a few reflections on the Roman criminal law in the Institutions of Marcianus. During the analysis it has been established that the Justinianic compilers drew heavily on this jurist's work. This was applied not only to individual institutions of criminal law (e.g. intentional and unintentional fault or crimen maiestatis), but also Marcianus's fragments repeatedly pointed to titles of the books in librii terribiles (books 47 to 48 in the Digest of Justinian).

Marcianus knew well the imperial constitutions (in particular rescripts), which was probably related to the work in the imperial office (scrinium libellorum). The imperial constitutions suit, primarily, the shape of criminal law in the imperial period, should be noted. One cannot exclude that the hypothetical work in the imperial office and a good knowledge of the imperial rescripts determined the frequent reaching for the Institutiones by the compilers of Justinian.

Key words: Roman criminal law, ancient Rome, jurist Marcianus

Słowa kluczowe: rzymskie prawo karne, starożytny Rzym, jurysta Marcianus

Rzymskie prawo karne nie stanowiło przedmiotu tak dogłębnych studiów jurysprudencji rzymskiej, jak prawo prywatne. Świadczy o tym liczba fragmentów zaczerpniętych z pism jurystów, poświęcona materii prawnokarnej, która została umieszczona w kompilacji justyniańskiej (księgi 47 oraz 48 - libri terribiles). Wśród jurystów parających się prawem karnym i piszącym zwarte dzieła poświęcone tej problematyce tytułem przykładu można wskazać Callistratusa (w szczególności księgi 4-6 jego dzieła de cognitionibus) ${ }^{1}$, Macera

1 Por. O. Lenel, Palingenesia Iuris Civilis, t. I, Lipsiae 1889, kol. 88-98. 
(dzieło de iudiciis publicis)², Modestyna (praca de poenis składająca się z 6 ksiąg) ${ }^{3}$, Papiniana ${ }^{4}$, Paulusa ${ }^{5}$ czy Ulpiana $^{6}$, piszących komentarze do różnych aspektów cudzołóstwa (adulterium) ${ }^{7}$. Nie można także pominąć bohatera niniejszego szkicu, któremu przypisuje się autorstwo monografii de iudiciis publicis ${ }^{8}$. Jednakże przedmiotem dalszych rozważań będzie inne dzieło tego jurysty - Institutiones ${ }^{9}$, w którym można odnaleźć kilka interesujących wątków prawnokarnych.

Przed przystąpieniem do właściwej analizy problemu, warto w kilku słowach przybliżyć sylwetkę samego jurysty. Brakuje rzetelnych informacji potwierdzających $w$ miarę precyzyjne daty życia Marcianusa ${ }^{10}$. Powszechnie przyjmuje się ${ }^{11}$, że żył i tworzył u schyłku II w. n.e. i pierwszej połowy III w. n.e.,

2 Ibidem, kol. 565-570. Także jurysta Saturninus napisał dzieło de iudiciis publicis - por. ibidem, t. II, kol. 1214-1216.

3 Ibidem, kol. 728-731.

4 Ibidem, kol. 804-809.

5 Ibidem, kol. 951-953.

6 Ibidem, t. II, kol. 931-939.

7 Adulterium doczekało się gruntownych badań nie tylko w literaturze światowej - zob. np. G. Rizzelli, Lex Iulia de adulteriis. Studi sulla disciplina di adulterium, lenocinium, stuprum, Bari 1997; T.A.J. McGinn, Prostitution, Sexuality, and the Law in Ancient Rome, New York 1998; C. Fayer, La Familia Romana: Aspetti Giuridici Ed Antiquari. Parte III: Concubinato, divorzi, adulterio, Roma 2005, s. 189-375; czy też w nauce polskiej - por. ostatnio wydaną pracę D. Stolarek, Adultera w świetle lex Iulia de adulteriis coërcendis, Lublin 2012.

8 O. Lenel, op. cit., t. I, kol. 675-680. Zob. także G. Gualandi, Legislazione imperiale e giurisprudenza, t. I, Milano 1963, s. 382-385.

9 Szersze rozważania w zakresie aspektów prawa prywatnego w Instytucjach Marcianusa przedstawił R. Lambertini, Sull'esordio delle Istituzioni di Marciano, „Studia et Documenta Historiae et Iuris"(dalej: SDHI) 1995, nr 61, s. 271 i nast.; L. Hernández-Tejero Garcia, La parte preliminar de las 'Instituciones' de Marciano, Estudios en homenaje al Prof. F. Hernandez-Tejero, t. II, Madrid 1994, s. 299-307. Por. także prace: F. Wieackera, Doppelexpemplare der Institutiones Florentins, Marcians und Ulpians, „Revue Internationale des Droits de l'Antiquite” (dalej: RIDA) 1949, nr 3, s. 577-607 czy A. Cenderelli, B. Biscotti, Produzione e scienza del diritto. Storia di un metodo, Torino 2005, s. 225 i nast., które ogólnie przybliżają cel oraz charakter Institutiones w działalności jurysprudencji rzymskiej.

L. de Giovanni, Giuristi severaini. Elio Marciano, Napoli 1989, s. 13; idem, Istituzioni, scienza giuridica, codici nel mondo tardo antico. Alle radici di una nuova storia, Roma 2007, s. 90; M. Bretone, Storia del diritto romano, wyd. 10, Bari 2004, s. 270. Por. także pracę S. Pietrini (L'insegnamento del diritto penale nei libri Institutionum, Napoli 2012, s. 47-52), w której autorka starała się podać w miarę precyzyjną datę aktywności pisarskiej jurysty, proponując cezurę czasową pomiędzy 217 r. n.e. a 222 r. n.e.

11 P. Jörs, Aelius 88, [w:] Real-Encyclopädie der classischen Altertumswissenschaft (dalej: RE), red. A. Pauly, G. Wissowa, t. I. 1, Stuttgatr 1893, szp. 523-525; F.M. de Robertis, Sulla cronologia degli scritti dei giuristi classici, „Rivista Italiana per le Scienze Giuridiche” n.s. (dalej: RISG) 1940, nr 15, s. 220-226; R. Orestano, Marciano Aelio, [w:] Novissimo Digesto Italiano (dalej: NNDI), t. X, Torino 1964, s. 254; W. Litewski, Jurysprudencja rzymska, Kraków 2000, s. 145; W. Kunkel, Die römsichen Juristen. Herkunft und soziale Stellung, Köln-Weimar-Wien 2001, s. 258-259; F. Wieacker, Römische Rechtgeschichte. Zweiter Abschnitt: Die Jurisprudenz vom frühen Prinzipat bis zum Ausgang der Antke, München 2006, s. 144-145; D. Liebs, Äelius Marcian. Ein Mittel des römischen Rechts in die hellenistiche Welt, „Zeitschrift der Savigny Stiftung für Rechtsgeschichte. Romanistische Abteilung" (dalej: ZSS) 2011, nr 128 , s. $46-48$. 
w szczególności w czasach panowania dynastii Sewerów. Mocnym argumentem potwierdzającym tę tezę jest poniższy fragment źródłowy:

\section{37, 14, 5, 1 (Marcianus libro tertio decimo institutionum): Imperatoris nostri rescripto cavetur, ut, si patronus libertum suum non aluerit, ius patroni perdat.}

Cytowany fragment odnosi się do kwestii wsparcia, jakiego miałby udzielać patron swojemu wyzwoleńcowi. Jurysta, powołując się na reskrypt cesarza, wyjaśnił, że zaniechanie tego obowiązku przez patrona skutkuje utratą prawa patronatu (ius patronatus). Pobieżna lektura tego fragmentu dowodzi, iż sam problem prawny, przed jakim stanął Marcianus, nie wydawał mu się zbytnio zawiły, skoro tak lapidarnie podszedł to tej kwestii.

Warto jednak kilka słów skreślić odnośnie do pojawiającej się w tekście frazy imperator noster, ponieważ jest ona kluczowa dla ustalenia okresu, w jakim żył Marcianus. Romaniści toczyli szereg sporów ${ }^{12}$ w zakresie jej rozumienia. Wydaje się, że nie ma większych obiekcji, aby podzielić zdanie S. Pietrini ${ }^{13}$ i przyjąć, że pojawiający się w cytowanym fragmencie zwrot imperator noster charakteryzował prawdopodobnie ostatniego z cesarzy z dynastii Sewerów cesarza Aleksandra Sewera. Dodatkowy argument, który może sprzyjać tej interpretacji, nawiązuje do aktywności piśmienniczej Marcianusa. Trzeba zaznaczyć, że jurysta ten wielokrotnie cytował reskrypty cesarskie, co mogłoby dowodzić jego zaangażowania instytucjonalnego w pracę kancelarii cesarskiej ${ }^{14}$. Należy jednak pamiętać, że jest to jeden z możliwych wariantów interpretacyjnych odnośnie do ustalenia okresu życia Marcianusa, a tym samym kwestia ta nie może być bezspornie rozstrzygnięta.

Literatura podręcznikowa, bo do takiej należy zaliczyć Institutiones (Instytucje), pojawiała się w działalności jurysprudencji stosunkowo późno ${ }^{15}$. Marcianus nie był jedynym jurystą piszącym dzieło o takim charakterze, ponieważ Institutiones przygotowali także Callistratus, Gaius, Florentinus, Paulus czy też Ulpian $^{16}$. Na szczególne podkreślenie zasługuje fakt, że najdłuższym podręcznikiem może poszczycić się właśnie Marcianus (16 ksiąg), a obok niego także

12 Przegląd literatury w tej materii znajduje się w pracy S. Pietrini, op. cit., s. 49-51.

13 Ibidem, s. 50.

14 Por. L. de Giovanni, L'età el principato. La giurisprudenza, [w:] Storia del diritto romano e linee di diritto proivato, red. A. Schiavone, Torino 2005, s. 202.

15 Por. W. Litewski, op. cit., s. 64.

16 Ibidem, s. 65-66. Por. także P. Jörs, op. cit., szp. 524; H. Krüger, Römische Juristen und ihre Werke, [w:] Studi in onore Pietro Bonfante, t. II, Milano 1930, s. 303-337; F. Wieacker, Doppelexpemplare..., s. 577; idem, Textstufen klassischer Juristen, Götingen 1960, s. 200 i nast.; D. Liebs, op. cit., s. 43;

S. Pietrini, op. cit., s. 23 i nast. 
Florentinus (12 ksiąg) $)^{17}$. W Institutiones Marcianusa można wyodrębnić dwie zasadnicze części - księgi 1-9 odnoszą się do prawa prywatnego, zaś pozostałe sześć dotyczy w zasadzie prawa publicznego ${ }^{18}$. Jednakże to, co wyróżnia podręcznik Marcianusa, to nie tylko jego objętość. W przeciwieństwie do Gaiusa jest $\mathrm{w}$ nim stosunkowo niewiele o zobowiązaniach ${ }^{19}$, ale $\mathrm{z}$ drugiej strony można tam znaleźć sporo informacji dotyczących leges publicae ${ }^{20}$, do których milcząco odniósł się Gaius. Przestawiając poszczególne gałęzie prawa prywatnego (w tym bardzo obszernie prawo spadkowe ${ }^{21}$ jurysta nie przywiązywał zbytnio wagi do treści, jakie umieszczał w konkretnej księdze ${ }^{22}$. Jako przykład może posłużyć poniższy fragment źródłowy:

D. 47, 19, 1 (Marcianus libro tertio institutionum): Si quis alienam hereditatem expilaverit, extra ordinem solet coerceri per accusationem expilatae hereditatis, sicut et oratione divi Marci cavetur.

Warto zaznaczyć, że kompilatorzy justyniańscy umieścili ten tekst w księdze 47, tytule 19, który był poświęcony kwestii zaboru rzeczy z jeszcze nieobjętego przez dziedzica spadku (crimen explitatae hereditatis) ${ }^{23}$. $\mathrm{Z}$ drugiej jednak strony inskrypcja fragmentu wskazuje, że Marcianus umieścił go w tej części Institutiones, gdzie znajdowało się prawo prywatne (księga trzecia) ${ }^{24}$.

Sam tekst nie uniemożliwia interpretacji, ponieważ jurysta wyjaśnił, iż dopuszczający się plądrowana nieobjętego spadku, ponosił odpowiedzialność na gruncie prawa karnego $\mathrm{w}$ ramach cognitio extra ordinem. Wyjaśniając tryb postępowania wobec sprawcy, Marcianus powołał się na rozstrzygnięcie (zapewne

Zob. F. Wieacker, Doppelexpemplare..., s. 596; W. Litewski, op. cit., 66; S. Pietrini, op. cit., s. 34, 52.

Por. S. Pietrini, op. cit., s. 57 z dalszą literaturą.

Zob. C. Ferrini, Intorno alle Istituzioni di Marciano, [w:] Opere di Cotardo Ferrini, t. II, red. E. Albertario, Milano 1929, s. 287-290. Por. W. Litewski, op. cit., s. 66; S. Pietrini, op. cit., s. 59, przyp. 66, 67-72.

L. de Giovanni, Giuristi severaini, s. 60 i nast.; idem, Istituzioni, scienza giuridica..., s. 91, przyp. 10. Por. także P. Jörs, op. cit., szp. 524; L. Wenger, Die Quellen des römischen Rechts, Wien 1953, s. 521; S. Pietrini, op. cit., s. 53.

G. Gualandi, op. cit., s. 372-378; F. Schulz, Storia della giurisprudenza romana, Firenze 1968, s. 303 i nast; S. Pietrini, s. 57. Por. W. Litewski, op. cit., s. 65-66.

22 S. Pietrini, op. cit., s. 75.

W polskiej literaturze problematykę tego przestępstwa syntetycznie przedstawił P.K. Grabowski, 'Crimen expilatio hereditatis', [w:] Culpa et poena. Z dziejów prawa karnego, red. M. Mikuła, Kraków 2009, s. 27-32.

Zob. także fragment D. 49, 16, 9, 1 (Marcianus libro tertio institutionum): Milites si heredes extiterint, possidere ibi praedia non prohibentur, w którym Marcianus wyjaśnił, że wyjatkiem od ogólnej zasady (ją z kolei jasno wyłożył w poprzedzajacym fragmencie - tj. D. 49, 19, 9) zakazu nabywania nieruchomości przez żołnierzy w trakcie trwania służby była sytuacja, gdy żołnierze zostawali powołani do spadku jako dziedzice. Po raz kolejny widoczny jest rozdźwięk między oryginalnym umieszczeniem tekstu w Institutiones Marcianusa (księga II) a jego umiejscowieniem przez kompilatorów (księga 49, tytuł 19 - poświęcony sprawom wojskowym - de re militari). Zob. także uwagi S. Pietrini, op. cit., s. 76 . 
reskrypt) cesarza Marka Aureliusza ${ }^{25}$. Jest to przy okazji jeden z wielu dowodów potwierdzający dobrą znajomość konstytucji cesarskich.

Innym przykładem, dobrze ilustrującym brak klarownego podziału w Instututiones pomiędzy materią prywatnoprawną a publicznoprawną, może być poniższy fragment źródłowy:

D. 48, 18, 5 (Marcianus libro secundo institutionum): Si quis viduam vel alii nuptam cognatam, cum qua nuptias contrahere non potest, corruperit, in insulam deportandus est, quia duplex crimen est et incestum, quia cognatam violavit contra fas, et adulterium vel stuprum adiungit. Denique hoc casu servi in personam domini torquentur.

Po lekturze tekstu trudno jest wyjaśnić, dlaczego cytowany fragment znalazł się w księdze drugiej Insitutiones Marcianusa ${ }^{26}$. Rozstrzygnięcie, jakiego podjął się jurysta wcale nie nawiązywało do prawa familijnego, co mogłoby wynikać z pojawiających się na samym początku tekstu terminów „wdowa” (vidua), „mężatka” (nupta) czy „krewna” (cognata), ale do prawa karnego.

Węzłowym problemem, przed jakim stanął jurysta, była kwestia wyjaśnienia czy zbieg przestępstw (duplex crimen), których podmiotem były kobiety (wdowa, mężatka czy też krewna) tj. przestępstwa cudzołóstwa lub stosunku seksualnego z kobietą niezamężną - (adulterium vel stuprum) z przestępstwem kazirodztwa (incestum) ${ }^{27}$ wpływał na wymiar kary ${ }^{28}$. Marcianus nie miał wątpliwości, że w przypadku wystąpienia zbiegu tych czynów należało wymierzyć karę w postaci deportatio in insulam ${ }^{29}$. Warto jeszcze zwrócić uwagę na jedną kwestię, pojawienie się w wypowiedzi jurysty terminu fas ${ }^{30}$, którego użycie

25 Szerzej o inicjatywie normatywnej cesarza pisał F. Arcaria, Oratio Marci. Giurisdizione e processo nella normazione di Marco Aurelio, Torino 2003, passim. Por. S. Pietrini, op. cit., s. 76.

26 Por. O. Lenel, op. cit., t. I, szp. 654. Warto wskazać, że G. Gualandi (op. cit., s. 373 i nast.) nie umieścił tego tekstu w księdze drugiej Institutones, ale też nie zaproponował innej jego lokalizacji w podręczniku Marcianusa.

Syntetyczną informację na temat znaczenia incestum dla starożytnych Rzymian przygotował G. Francosi, Clan gentilizio e strutture monogamiche. Contributo alla storia della famiglia romana, wyd. 3, Napoli 1983, s. 149-170. Szersze zaś rozważania w zakresie incestum skreśliła ostatnio J. Misztal-Konecka, Incestum w prawie rzymskim, Lublin 2007, passim.

28 A. Guarino, Studi sull', incestum”, ZSS 1943, nr 63, s. 202 i nast.; A. Guareschi, Le note di Marciano ai 'de adulteris libri duo' di Papiniano, "Index. Guaderni camerti di studi romanistici. International Survey of Roman Law" (dalej: Index) 1993, nr 21, s. 460 i nast.; J. Misztal-Konecka, op. cit., s. 102.

Na temat dyskusji w nauce co do autentyczności tego tekstu oraz sankcji karnej w nim wymienionej zob. A. Guarino, op. cit., s. 203-206; G. Guareschi, op. cit., s. 474, przyp. 31; J. Misztal-Konecka, op. cit., 167.

30 Szczegółowe rozważania w zakresie znaczenia fas oraz nefas dla życia Rzymian przeprowadził R. Orestano, Dal ius al fas. Rapporto fra diritto divino e umano in Roma dall'età primitiva all'età classica, „Bulletino dell'Istituto di Diritto Romano" (dalej: BIDR) 1939, nr 46, s. 194-273 oraz F. Sini, Bellum nefandum. Virgilio e il problema di "diritto internazonale antico", Sassari 1991, s. 83-145. Por. także 
wskazuje na wplecenie w wywód jurysty pierwiastków sakralnych. Charakterystyczne jest, że Marcianus, tworzący u schyłku okresu klasycznego, zaprzągł do argumentacji sferę prawa sakralnego. Przyjmuje się tezę, iż Rzymianie darzyli dużą estymą oraz odnosili się z szacunkiem nie tylko do prawa świeckiego.

Warto wskazać, że analizowany fragment kompilatorzy justyniańscy umieścili $\mathrm{w}$ tzw. libri terribiles. Zdumienie jednak może wynikać z faktu, iż tekst ten został zamieszczony $\mathrm{w}$ tytule 48 księgi 18 poświęconej torturom (de tormentis), ponieważ tej kwestii Marcianus poświęcił zaledwie jedne, ostatnie zdanie swego wywodu. Jednak kwestia, jaką poruszył w tak lakoniczny sposób nie była bez znaczenia. Chodziło bowiem o to, czy niewolnik (sevus) mógł być poddany torturom na okoliczność popełnienia przez jego właściciela wymienionych wyżej przestępstw ${ }^{31}$. Dość wspomnieć, że wśród romanistów nie ma jednolitego zdania $\mathrm{w}$ tej materii, a przeważające stanowisko uznaje zakaz stosowania tortur względem niewolnika $\mathrm{w}$ przypadku podejrzewania jego pana o popełnienie incestum ${ }^{32}$. Co więcej, lektura tekstu zdaje się dowodzić, że wspomniany zakaz tortur odnosiłby się także do oskarżeń o stuprum $^{33}$. Nie wdając się $\mathrm{w}$ głębszą polemikę z przytoczonymi zwolennikami i przeciwnikami ${ }^{34}$ tej tezy, warto zwrócić uwagę na inną kwestię, jaką jest autentyczność tego fragmentu. Romaniści dowodzą, że przedmiotowy tekst został zniekształcony przez kompilatorów justyniańskich ${ }^{35}$, co tym samym wpłynęło na jego pierwotne brzmienie. Tym samym przyjmuje się, że to nie Marcianus dostrzegał konieczność rozszerzenia tortur wobec niewolników, ale było to dążenie komisji kodyfikacyjnej cesarza Justyniana zmierzające do rozciągnięcia tego środka dowodowego na przypadki stuprum ${ }^{36}$. Stąd też biorąc pod uwagę cały kontekst źródła i jego prawdopodobną interpolację, nie powinno budzić zdumienia jego umieszczenie w księdze 48, tytule 18, poświęconym torturom. Choć $\mathrm{w}$ istocie, lektura całego tekstu zdaje się dowodzić, że kwestia dowodowa (w postaci stosowania tortur) jest tu wątkiem drugoplanowym.

ostatnio J. Rüpke, Rationalizing Religious Practice. The Pontifical Calendar and the Law, [w:] Law and Religion in the Roman Republic, red. O. Tellegen-Couperus, Leiden 2012, s. 103-106; idem, Religion in Republican Rome. Rationalization and Ritual Change, Philadelphia 2012, s. 104-110.

31 Wątpliwości nie budzi jedna kwestia - gdy właściciel był podejrzewany o popełnienie adulterium bądź dochodziło do zbiegu adulterium z incestum, totutury względem niewolników były dopuszczone - zob. J. Misztal-Konecka, op. cit., s. 134 i nast. s. 154

33 Zob. J. Misztal-Konecka, op. cit., s. 134 i nast., s. 154-155 i podane przez badaczkę argumenty przeczą tej tezie.

34 Zob. np. G. Guareschi, op. cit., s. 474, przyp. 31.

35 W szczególności wywody A. Guarino, op. cit., s. 203-205; J. Misztal-Konecka, op. cit., s. 155, 167.

36 J. Misztal-Koncecka, op. cit., s. 155. 
Dotychczasowe uwagi koncentrowany się na ukazaniu braku spójności treściowej Instituiones Marcianusa, ponieważ, w poszczególnych księgach pomieszana była kwestia prawa prywatnego oraz prawa publicznego. Jednakże będąca przedmiotem zainteresowania niniejszego szkicu materia prawa karnego - co do zasady - znajdowała się końcowych księgach podręcznika, a już w szczególności w księdze czternastej.

Kompilatorzy justyniańscy obficie czerpali z Insitutiones Marcianusa. Dzięki passusom zaczerpniętym z pracy jurysty (a także innych przedstawicieli jurysprudencji, w osobach np. Papiniana, Paulusa czy Ulpiana) możliwe jest poznanie m.in. lex Iulia de vi publica ${ }^{37}$. Warto odnotować, że fragment autorstwa Marcianusa nie tylko rozpoczyna tytuł 6 księgi 48 (ad legem Iuliam de vi publica), a także jako pierwszy ${ }^{38}$ jest przytaczany przez kompilatorów justyniańskich $\mathrm{w}$ odniesieniu do innych regulacji prawnych, jak np. lex Cornelia de sicariis et veneficis ${ }^{39}$ dotyczącej crimen inter sicarios oraz veneficium. Pierwszy z wspominanych czynów odnosił się do zbrojnych aktów bandytyzmu, polegających na stwarzaniu zagrożenia bezpieczeństwa publicznego poprzez publiczne noszenie broni oraz dokonywanie mordów, grabieży i podpaleń ${ }^{40}$. Przestępstwo veneficium złożone było z czynów polegających na wytwarzaniu, sprzedawaniu, kupowaniu i aplikowaniu trucizn - venena ${ }^{41}$. Nie wdając się w szczegółową analizę problemów związanych z tą - jakże ważną - regulacją prawną, jako kolejny przykład inspiracji dla kompilatorów justyniańskich Instytucjami Marcianusa można przywołać lex Pompeia de parricidis ${ }^{42}$, lex Cornelia de fal-

37 Nie jest do końca jasne, czy istniała jedna ustawa obejmująca swoim zakresem vis publica oraz vis privata, czy też istniały dwie odrębne regulacje prawne. Podobne obiekcje dotyczą autorstwa ustawy - przypisywanej Cezarowi bądź Augustowi - por. G. Rotondi, Leges publice populi Romani. Elenco cronologico con una introduzione sull'attività legislativa dei comizi romani, Hildesheim 1966, s. 450; G. Longo, lex Julia de vi publica e lex Julia de vi privata, [w:] NNDI, t. IX, Torino 1961, s. 812; M. Balzarini, Ricerche in tema di danno violento e rapina nel diritto romano, Padova 1969, s. 194 i nast.; K. Amielańczyk, Crimina legitima w rzymskim prawie publicznym, Lublin 2013, s. 295.

Zawarte w Digesta Iustiniani fragmenty przypisywane Marcianusowi dotyczą zdefiniowania crimen ambitus oraz wskazania okoliczności wyłączających popełnienie tego czynu - zob. D. 48, 11, 1 (Marcianus libro quatro decimo institutionum): pr. Lex Iulia repetundarum pertinet ad eas pecunias, quas quis in magistratu potestate curatione legatione vel quo alio officio munere ministeriove publico cepit, vel cum ex cohorte cuius eorum est. 1. Excipit lex, a quibus licet accipere: a sobrinis propioreve gradu cognatis suis, uxore. Warto tu odnotować lex Iulia de ambitu z 18 r. p.n.e., której autorstwo przypisuje się Augustowi, odnosiła się do przestępstwa wyborczego (crimen ambitus) i była jedną z wielu ustaw poświęconych tej kwestii - por. P. Kołodko, Ustawodawstwo rzymskie w sprawach karnych. Od ustawy XII tablic do dyktatury Sulli, Białystok 2012, s. 67-103; K. Amielańczyk, Crimina legitima..., s. 329-336. Zob. także G. Rotondi, op. cit., s. 443. czyk, "Lex Cornelia de sicariis et veneficis”. Ustawa Korneliusza Sulli przeciwko nożownikom i trucicielom, Lublin 2011, passim.

K. Amielańczyk, Crimina legitima..., s. 163. Ibidem. 
sis ${ }^{43}$, czy lex Cornelia de peculatu $u^{44}$. Tak znacząca częstotliwość sięgania do Institutiones Marcianusa przez kompilatorów cesarza Justyniana może stanowić dowód na jego dużą znajomość prawa karnego. Jest to o tyle ciekawe, że passusy zaczerpnięto przede wszystkim z pracy o charakterze elementarnym, podręcznikowym. Być może zwięzły przekaz ${ }^{45}$, charakteryzujący fragmenty pochodzące z Instytucji Marcianusa, był przekonywającym argumentem na korzyść ich wykorzystania podczas przygotowywania kodyfikacji justyniańskiej. Nie można także wykluczyć, iż inne dzieła jurysty (np. de iudiciis publicis) w bardziej szczegółowy sposób podchodziły do wybranych problemów prawa karnego, a kompilatorzy poszukiwali $\mathrm{w}$ miarę syntetycznych informacji poświęconych prawu karnemu. Tutaj chyba należy upatrywać dużej atrakcyjności Institutiones Marcianusa, z punktu widzenia komisji kodyfikacyjnej i tak częstego sięgania do tej pracy jurysty.

Posiłkując się systematyką przestępstw umieszczonych w księdze $48 \mathrm{Di}$ gestia Iustiniani (począwszy od D. 48,4, a skończywszy na D. 48,15), można na przykładzie wybranych fragmentów Institutiones Marcianusa - pokazać ich wpływ na kształt prawa karnego, nie tylko czasów współczesnych Justynia-

jak: D. 48, 9, 3; D. 48, 9, 5. Szerzej o parricidium pisał M. Jońca, Parricidium w prawie rzymskim, Lublin 2008, passim; por. K. Amielańczyk, Crimina legitima..., s. 221-236. Zob. także L. Fanizza, Il parricidio nel sistema della «lex Pompeia», "Labeo. Rassegna di diritto Romano” (dalej: Labeo) 1979, t. 25, z. 3, s. 266-288; R. Rilinger, Humiliores-Honestiores. Zu einer sozialen Dichotomie im Strafrecht der romischen Kaiserzeit, München 1988, s. 181-206.

D. 48,10, 1pr.-13 oraz dalsze fragmenty autorstwa Marcianusa zgromadzone w tytule 10 księgi 48. Zob. także K. Amielańczyk, Crimina legitima..., s. 183-200.

44 W tym przypadku przekazy pochodzące z Institutiones Marcianusa uzupełniają materię poświęconą przestępstwu defraudacji publicznych pieniędzy (crimen peculatus) poprzez dookreślenie znamion czynu oraz przedstawienie sankcji karnej - zob. D. 48, 13, 4 oraz D. 41, 13, 5 (3,4). Najpełniej crimen peculatus przybliżył F. Gnoli, Ricerche sul crimen peculatus, Milano 1979, passim. Ostatnio w kwestii tego przestępstwa syntetycznie wypowiedział się K. Amielańczyk, Crimina legitima..., s. 314-329.

45 Warto w tym kontekście wspomnieć o przestępstwie zdzierstwa (wymuszenia) pieniędzy i innych świadczeń w związku z pełnioną funkcją urzędniczą - crimen repetundarum. Autorstwo lex Iulia de repetundis z 59 r. p.n.e. przypisuje się Cezarowi (por. G. Rotondi, op. cit., s. 389-391), a tytuł 11 księgi 48 otwiera następujący przekaz Marcianusa - D. 48, 11, 1pr-1 (Marcianus libro quatro decimo institutionum): Lex Iulia repetundarum pertinet ad eas pecunias, quas quis in magistratu potestate curatione legatione vel quo alio officio munere ministeriove publico cepit, vel cum ex cohorte cuius eorum est. 1. Excipit lex, a quibus licet accipere: a sobrinis propioreve gradu cognatis suis, uxore. Charakterystyczne jest, że Marcianus, komentując treść tej ustawy, przedstawił autorski jej komentarz, a nie zacytował wprost jej brzmienia. Ponadto przybliżył konstrukcję crimen repetundarum od strony przedmiotu przestępstwa (czyli pieniędzy), a nie opisu czynności zabronionych ustawą, co z reguły cechowało język republikańskich ustaw karnych. Zob. K. Amielańczyk, Crimina legitima..., s. 250-251. Passus wyraźnie wskazuje, że ustawa odnosiła się do pieniędzy (pecunia) przyjętych przez osoby piastujące określone funkcje publiczne oraz personel pomocniczy. Jednakże ustawa dopuszczała przyjmowanie pieniędzy od członków najbliższej rodziny (kuzyni bliższego stopnia, krewni oraz żona). Przedmiotowy przekaz może być traktowany jako potwierdzenie dobrego kunsztu prawniczego Marcianusa. Jurysta wyzbył się tu charakterystycznej dla jurysprudencji cechy cytowania przepisów ustawy, aby samodzielnie przybliżyć pojęcie repetundae. 
nowi. Punkt wyjścia do dalszych rozważań może stanowić analiza poniższego fragmentu źródłowego:

D. 48, 4, 3 (Marcianus libro quarto decimo institutionum): Lex duodecim tabularum iubet eum, qui hostem concitaverit quive civem hosti tradiderit, capite puniri. Lex autem Iulia maiestatis praecipit eum, qui maiestatem publicam laeserit, teneri: qualis est ille, qui in bellis cesserit aut arcem tenuerit aut castra concesserit. Eadem lege tenetur et qui iniussu principis bellum gesserit dilectumve habuerit exercitum comparaverit: quive, cum ei in provincia successum esset, exercitum successori non tradidit: quive imperium exercitumoe populi Romani deserverit: quive privatus pro potestate magistratuve quid sciens dolo malo gesserit: quive quid eorum, quae supra scripta sunt, facere curaverit.

Przedmiotem zainteresowania jurysty była kwestia pojmowania znamion crimen maiestatis ${ }^{46}$, znanego już ustawie XII tablic. Marcianus cytując lex duodecim tabularum, potwierdził nie tylko obowiązywanie tej regulacji prawnej, ale też wskazał, iż archaiczna forma popełnienia tego przestępstwa, polegająca na podburzaniu wroga i wydawaniu mu rzymskich obywateli, w dalszym ciągu znajdowała się $\mathrm{w}$ porządku prawnym ${ }^{47}$. Jurysta dodał ${ }^{48}$ do znamion przestępstwa, określonego przez lex Iulia de maiestate ${ }^{49}$, następujące stany faktyczne: naruszenie publicznego majestatu przez poddawane się wrogom podczas wojny czy lekkomyślne ustępowanie z twierdzy lub obozu, prowadzenie wojny, organizowanie poboru i przygotowywanie armii bez zezwolenia cesarza, brak przekazania przez ustępującego namiestnika prowincji władzy wojskowej swemu następcy, porzucenie władzy (imperium) albo armii ludu rzymskiego, świadome działanie prywatnego obywatela w złym zamiarze w charakterze urzędnika, a także doprowadzenie do któregokolwiek z zachowań ${ }^{50}$.

Z cytowanego źródła wynika, iż w konstrukcji crimen maiestatis funkcjonującej w okresie cesarstwa można dostrzec republikańskie wzorce, wyrażone ustawą XII tablic. Trzeba jednak dodać, że Marcianus nawiązując do lex du-

46 Szczegółowe rozważania dotyczące tego przestępstwa przedstawił R. Bauman, The crimen maiestatis in the Roman Republic and the Augustan Principate, Johhannesburg 1967, passim; a w polskiej literaturze problemem tym zajmowała się M.H. Dyjakowska, Crimen laesae maiestatis. Studium nad wpływami prawa rzymskiego w dawnej Polsce, Lublin 2010, passim.

Por. K. Amielańczyk, Crimina legitima..., s. 239. Zob. także K. Amielańczyk, Crimina legitima..., s. 238.

Znane są dwie ustawy (o tej samej nazwie) poświęcone kwestii crimen maiestatis - autorstwo jednej z nich przypisuje się Cezarowi (zob. G. Rotondi, op. cit., s. 422), drugiej zaś Augustowi ibidem, s. 453; G. Longo, lex Julia maiestatis, [w:] NNDI, t. IX (1961), s. 813. Nie da się jednoznacznie rozstrzygnąć, czy cytowana w Digesta Iustiniani ustawa przypisywana jest Cezarowi czy też Augustowi - por. K. Amielańczyk, Crimina legitima..., s. 237.

K. Amielańczyk, Crimina legitima..., s. 239-240. 
odecim tabularum nie wtrącił do swego komentarza charakterystycznej dla republikańskiego ustawodawstwa karnego frazy dolo malo (sciens, dolo malo) ${ }^{51}$. Nie ulega przy tym wątpliwości, że republikańska koncepcja crimen maiestatis kładła nacisk ma świadome ${ }^{52}$, a zatem umyślne działanie sprawcy. Trudno bowiem sobie wyobrazić, aby można było podburzać wroga w sposób nieumyślny. Nieco zagadkowe $\mathrm{w}$ tym kontekście może wydawać się odwołanie do działania „z premedytacją", „umyślnego" „w złym zamiarze” - tj. dolo malo (sciens dolo malo), jakie jest widoczne w końcowej części fragmentu autorstwa Marcianusa. Na pierwszy rzut oka wygląda to na „przypomnienie” przez jurystę umyślności jako podstawowego znamienia definiującego to przestępstwo ${ }^{53}$. Trzeba jednak pamiętać, iż crimen maiestatis od okresu pryncypatu będzie ewoluowało w kierunku obrazy majestatu samego cesarza (crimen laese maiestatis). Nie można przy tym wykluczyć, że majestat cesarza mógł zostać naruszony w inny sposób niż świadome i celowe działanie sprawcy. Stąd też dodanie frazy dolo malo miało istotne znaczenie i wydawało się koniecznością ${ }^{54}$, a nie zwykłym zabiegiem redakcyjnym dokonanym przez jurystę.

Lektura zachowanych fragmentów Institutiones Marcianusa pozwala na wysnucie wniosku, iż w tak elementarnym dziele, które spełniało funkcję dydaktyczną, znaleźć można informacje dotyczące stopnia zawinienia sprawcy oraz form stadialnych przestępstwa. Właściwy punkt wyjścia do rozważań stanowi poniższy fragment źródłowy ${ }^{55}$ :

D. 48, 8, 1, 3 (Marcianus libro quatro decimo institutionum): Divus Hadrianus rescripsit eum, qui hominem occidit, si non occidendi animo hoc admisit, absolvi posse, et qui hominem non occidit, sed vulneravit, ut occidat, pro homicida damnandum: et ex re constituendum hoc: nam si gladium strinxerit et in eo percusserit, indubitate occidendi animo id eum admisisse: sed si clavi percussit aut cuccuma in rixa, quamvis ferro percusserit, tamen non occidendi animo. Leniendam poenam eius, qui in rixa casu magis quam voluntate homicidium admisit.

51 Szerzej o jej znaczeniu dla legislacji karnej okresu republiki pisał ostatnio K. Amielańczyk, Crimina legitima..., s. 241-242.

52 Więcej informacji o republikańskiej koncepcji winy umyślnej można znaleźć u K. Amielańczyka, Lex Cornelia..., s. 136-140.

Zob. R. Rilinger, op. cit., s. 207-218; D. Mantovani, Il problema d'origine dell'accusa popolare: dalla "quaestio" unilaterale alla "quaestio" bilaterale, Padova 1989, s. 14 i nast.

54 Por. ibidem, s. 242.

55 Trzeba tu wspomnieć, iż bardzo zbliżony stan faktyczny przekazał Ulpian w Coll. 1, 6, 1-4. Na temat wzajemnej relacji tekstu zawartego w Collatio do cytowanego przekazu Marcianusa wypowiedział się M. Balzarini, Appunti sulla «rixa» nel diritto criminale romano, Labeo 1982, nr 28, z. 1, s. 20 i nast. Zob. także K. Amielańczyk, Rzymskie prawo karne w reskryptach cesarza Hadriana, Lublin 2006, s. 73; idem, Crimina legitima..., s. 141. Por. G. Gualandi, op. cit., t. II, s. 78; G. Polara, Marciano e l'elemento soggetivo del reato. Delinquintur aut proposito aut impetus aut casu, BIDR 1974, t. 77, s. 112 i nast. 
Kompilatorzy justyniańscy umieścili ten fragment z Instytucji Marcianusa w tytule 8 księgi 48, poświęconej lex Cornelia de sicariis et veneficis ${ }^{56}$. Jurysta przedstawił tu treść reskryptu cesarza Hadriana, w którym można znaleźć odwołania do stopnia zawinienia sprawcy, a tym samym popełnienia przez niego przestępstwa umyślnego bądź nieumyślnego ${ }^{57}$. Podstawowym kryterium wyodrębnienia tych czynów było przypisanie sprawcy zamiaru zabicia (animus occidendi $)^{58}$. Hadrian wyjaśnił bowiem, iż ten, kto zabił człowieka, lecz nie można przypisać mu zamiaru zabicia - powinien zostać uniewinniony ${ }^{59}$. Z drugiej zaś strony, gdy sprawca nie zabił, ale zranił kogoś z zamiarem zabicia, powinien odpowiadać jak za zabójstwo. W dalszej części przekazu można odnaleźć swoiste wytyczne, jakie Hadrian skierował do pytającego go sędziego, pomagające w identyfikacji zawinienia sprawcy, a tym samym dokonania oceny czynu przestępnego ${ }^{60}$. Gdy sprawca używał miecza (gladius) i nim uderzył kogoś, nie było wątpliwości, że czynił to z zamiarem zabicia (animus occidendi). Natomiast, gdy do zadawania ciosów posłużył się kluczem lub patelnią, bądź innym metalowym narzędziem podczas kłótni (rixa $)^{61}$, nie można mu było przypisać zamiaru zabicia (animus occidendi).

Interpretacja tego fragmentu nie nastręcza większych obiekcji. Przekazany przez Marcianusa reskrypt Hadriana potwierdza rozróżnianie przestępstw popełnionych umyślnie oraz nieumyślnie. Podkreślenia wymaga to, że tę dy-

56 Wpływ winy umyślnej i nieumyślnej na zakres odpowiedzialności karnej był już spotykany w prawie starożytnej Grecji, zob. D. Nörr, Causam mortis praebere, [w:] The Legal Mind. Essays for Tony Honoré, red. N. MacCormik, P. Birks, Oxford 1986, s. 210-212. Problematykę winy w ustawie Sulli przedstawił K. Amielańczyk, 'Dolus malus-animus occidendi'. The Problem of Guilt In the 'lex Cornelia de sicariis et veneficis', [w:] Au-delà des frontières. Mélanges de droit romain offers à Witold Wołodkiewicz, red. M. Zabłocka, J. Krzynówek, J. Urbanik, Z. Służewska, t. 1, Varsovie 2000, s. 1-17.

Por. K. Amielańczyk, Rzymskie prawo karne..., s. 72.

Por. G. Polara, op. cit., s. 112.

Por. K. Amielańczyk, Rzymskie prawo karne..., s. 73.

Zgodzić się trzeba ze zdaniem K. Amielańczyka (Rzymskie prawo karne..., s. 73, przyp. 83), iż termin rixa, w kontekście tej wypowiedzi jurysty, trzeba interpretować w znaczeniu „kłótni”, „sprzeczki”, a nie „bijatyki” (w tym ostatnim znaczeniu tego terminu zachowane źródła prawnicze i literackie analizował W. Mossakowski, Rixa, czyżby starożytne chuligaństwo?, [w:] Ochrona bezpieczeństwa i porząku publicznego w starożytnym Rzymie, red. K. Amielańczyk, A. Dębiński, D. Słapek, Lublin 2010, s. 197-209; por. także nieco wcześniejszy, obszerny tekst napisany przez M. Balzariniego, op. cit., s. 17-42). W innym przypadku rozstrzygnięcie zaproponowane przez Hadriana stałoby się mało czytelne. Trzeba jednak wspomnieć, że W. Mossakowski (op. cit., s. 203) zauważył, że sporny fragment, tj. [...] sed si clavi percussit aut cuccuma in rixa, quamvis ferro percusserit, tamen non occidendi animo [...], a w szczególności pojawiająca się w nim fraza quamvis ferro może być interpretowana jako ,jakąkolwiek bronią” (a nie wąsko - „metalowym przedmiotem”, jak postulował K. Amielańczyk, op. cit.), co w konsekwencji prowadzi do przyjęcia, iż termin rixa odnosiłby się do chuligańskiej bójki. Por. także podejście G. Polary, op. cit., s. 112, który dostrzega brak logicznego działania kancelarii cesarskiej, nieupatrującej możliwości przypisania animus occidendi sprawcy uderzającego patelnią z zamiarem zabicia. 
chotomię $\mathrm{w}$ zakresie stopnia zawinienia sprawcy znało już rzymskie prawo karne okresu królewskiego i wczesnej republiki ${ }^{62}$. Jednakże to cesarz Hadrian jawi się tutaj jako konsekwentny zwolennik precyzyjnego zbadania zamiaru sprawcy, jako istotnego znamienia czynu karalnego ${ }^{63}$. Warto też wskazać, że cytowane źródło jest dowodem na konieczność uregulowania odpowiedzialności za formę stadialną przestępstwa, jaką jest usiłowanie zabójstwa ${ }^{64}$. Tak bowiem trzeba interpretować tę część reskryptu, gdzie cesarz wyjaśnił, jak traktować sprawcę, któremu można przypisać animus occidendi, lecz jego działanie nie doprowadziło do pożądanego skutku, jakim była śmierć. Zrównanie odpowiedzialności karnej zarówno sprawcy, który zamierzony skutek osiągnął, z tym, który owego skutku (działając) nie osiągnął wynika z dużego ładunku złej woli tego ostatniego. Nie ma tu większego znaczenia, dlaczego nie doszło do dokonania zabójstwa. Istotne było nastawienie sprawcy, który swoim zachowaniem dążył do popełnienia przestępstwa, a jedynie okoliczności towarzyszące jego zamiarowi udaremniły zbrodniczy rezultat. Pejoratywne zachowanie sprawcy, który w rezultacie nie osiągnął celu, nie mogło przecież pozostać bezkarne. Bezsprzecznie widoczny animus occidendi, przypisany sprawcy był wystarczają przesłanką do pociągnięcia go do odpowiedzialności karnej.

Warto na chwilę zatrzymać się także nad ostatnim zdaniem przytoczonego źródła. Jurysta stwierdził bowiem, że lżej ukaranym powinien być ten, kto $\mathrm{w}$ trakcie kłótni działając casu magis quam voluntate doprowadził kogokolwiek do śmierci. Użyta przez Marcianusa terminologia (casu magis quam voluntate) wskazuje, iż jest mało prawdopodobne, aby taki zwrot znalazł się w treści reskryptu i należy go traktować jako dopisek jurysty. Tym bardziej nie można go postrzegać jako próby wprowadzenia pośredniej kategorii pomiędzy czynami popełnionymi umyślnie i nieumyślnie. Raczej jest to rezultat niedoskonałości tego dychotomicznego podziału, który musiał być dostrzegany podczas rozwiązywania skomplikowanych stanów faktycznych ${ }^{65}$. Nie jest przy tym wykluczone, iż przedmiotowy dopisek może być powiązany z dydaktycznym charakterem dzieła Marcianusa. Zakładając, że adresatami Institutiones byli nie tylko potencjalni studenci, ale również ówczesny wymiar sprawiedliwości ${ }^{66}$, uwagę jurysty można traktować jako wskazówkę w zakresie interpretacji niejednoznacznego stanu faktycznego, gdzie istniała wątpliwość w przed-

62 Por. uwagi K. Amielańczyka, Rzymskie prawo karne..., s. 64-65; idem, Lex Cornelia..., s. $136-137$.

Zob. D. 48, 8, 14 (Callistratus libro sexto de cognitionibus): Divus Hadrianus in haec verba rescripsit: "in maleficiis voluntas spectatur, non exitus", zob. także uwagi K. Amielańczyka, Crimina legitima..., s. 149-150, odnoszące się do kontekstu, w jakim trzeba interpretować ten urywek Callistratusa.

Por. K. Amielańczyk, Rzymskie prawo karne..., s. 72; idem, Crimina legitima..., s. 151-152. 
miocie przypisania sprawcy winy umyślnej bądź nieumyślnej. Zaproponowana przez Marcianusa formuła casu magis quam voluntate pozwalała odwołać się do kompromisowego wyboru rozwiązania w zakresie odpowiedzialności karnej, przejawiającego się $\mathrm{w}$ ferowaniu lżejszych $\operatorname{kar}^{67}$.

Krótki szkic poświęcony problematyce prawa karnego w dziele Marcianusa skłania do wysnucia kilku wniosków. Institutiones Marcianusa będąc podręcznikiem do nauki prawa, zawierały dużo wątków prawnokarnych, w stosunku do podobnych prac powstających $w$ tym samym okresie. Zwięzła formuła przekazu jurysty musiała być atrakcyjna dla kompilatorów justyniańskich, skoro tak ochoczo sięgali po tę pracę. Co więcej, fragmenty źródłowe zawarte w Digesta Iustiniani potwierdzają, że zwięzły, syntetyczny przekaz poszczególnych instytucji prawa karnego (wina umyślna i nieumyślna, problematyka tortur) czy też określanie znamion czynu zabronionego (przy crimen laesae maiestatis bądź crimen ambitus) spełniał oczekiwania komisji kodyfikacyjnej cesarza Justyniana. Tym wypada tłumaczyć tak częste przywoływanie pracy Marcianusa w księgach poświęconych prawu karnemu (libri terribiles) w Digesta Iustiniani. Trzeba przy tym pamiętać, że przeprowadzona analiza dowiodła, iż sam autor nie przywiązywał zbytniej wagi do precyzyjnego umieszczania informacji $\mathrm{z}$ zakresu prawa karnego jedynie w końcowej partii Institutiones. Przeplatanie przez Marcianusa wątków prawa karnego z prywatnoprawnymi jest dobrze udokumentowane w całych Institutiones.

Dobra znajomość reskryptów cesarskich dowodzi raczej aktywności samego jurysty w kancelarii cesarskiej Aleksandra Sewera, niż cytowanie ich treści z innego, wtórnego mu źródła wiedzy. Liczne odwoływanie się do tej formy konstytucji cesarskich wskazuje na ich doniosłą rolę $\mathrm{w}$ zakresie tworzenia norm prawnokarnych.

Krótkie refleksje poświęcone Instytucjom Marcianusa skłaniają do wniosku, iż jest to praca zawierająca szereg wartościowych informacji odnoszących się do rzymskiego prawa karnego. Nie bez znaczenia wydaje się tu postać autora, który na tyle jasno przedstawiał instytucje prawnokarne, że komisja kodyfikacyjna cesarza Justyniana nie wahała się przed licznymi odwołaniami do Institutiones. Dzięki temu można poznać nie tylko kształt rzymskiego prawa karnego, ale także, chociażby częściowo, zapoznać się z problematyką, jaką Marcianus prezentował swoim odbiorcom.

67 Por. K. Amielańczyk, Rzymskie prawo karne..., s. 76. 


\section{Bibliografia}

Amielańczyk K., 'Dolus malus-animus occidendi'. The Problem of Guilt In the 'lex Cornelia de sicariis et veneficis', [w:] Au-delà des frontières. Mélanges de droit romain offers à Witold Wołodkiewicz, red. M. Zabłocka, J. Krzynówek, J. Urbanik, Z. Służewska, t. 1, Varsovie 2000.

Amielańczyk K., "Lex Cornelia de sicariis et veneficis”. Ustawa Korneliusza Sulli przeciwko nożownikom i trucicielom, Lublin 2011.

Amielańczyk K., Crimina legitima w rzymskim prawie publicznym, Lublin 2013.

Arcaria F., Oratio Marci. Giurisdizione e processo nella normazione di Marco Aurelio, Torino 2003.

Balzarini M., Appunti sulla «rixa» nel diritto penale romano, „Labeo. Rassegna di diritto Romano" 1982, t. 28, z. 1.

Balzarini M., Ricerche in tema di danno violento e rapina nel diritto romano, Padova 1969.

Bauman R., The crimen maiestatis in the Roman Republic and the Augustan Principate, Johhannesburg 1967.

Bretone M., Storia del diritto romano, wyd. 10, Bari 2004.

Cenderelli A., Biscotti B., Produzione e scienza del diritto. Storia di un metodo, Torino 2005.

Dyjakowska M.H., Crimen laesae maiestatis. Studium nad wplywami prawa rzymskiego $w$ dawnej Polsce, Lublin 2010.

Fanizza L., Il parricidio nel sistema della jlex Pompeia ¿, „Labeo. Rassegna di diritto Romano" 1979, t. 25, z. 3.

Fayer C., La Familia Romana: Aspetti Giuridici Ed Antiquari. Parte III: Concubinato, divorzi, adulterio, Roma 2005.

Ferrini C., Intorno alle Istituzioni di Marciano, [w:] Opere di Cotardo Ferrini, red. E. Albertario, t. II, Milano 1929.

Francosi G., Clan gentilizio e strutture monogamiche. Contributo alla storia della famiglia romana, wyd. 3, Napoli 1983.

de Giovanni L, Istituzioni, scienza giuridica, codici nel mondo tardo antico. Alle radici di una nuova storia, Roma 2007.

de Giovanni L., Giuristi severaini. Elio Marciano, Napoli 1989.

de Giovanni L., L'età el principato. La giurisprudenza, [w:] Storia del diritto romano e linee di diritto prvivato, red. A. Schiavone, Torino 2005.

Gnoli F., Ricerche sul crimen peculatus, Milano 1979.

Grabowski P.K., 'Crimen expilatio hereditatis', [w:] Culpa et poena. Z dziejów prawa karnego, red. M. Mikuła, Kraków 2009.

Gualandi G., Legislazione imperiale e giurisprudenza, t. I-II, Milano 1963.

Guareschi A., Le note di Marciano ai 'de adulteris libri duo' di Papiniano, „Index. Guaderni camerti di studi romanistici. International Survey of Roman Law", 1993, nr 21. 
Guarino A., Studi sull',incestum”, "Zeitschrift der Savigny Stiftung für Rechtsgeschichte. Romanistische Abteilung" 1943, nr 63.

Hernández-Tejero Garcia L., La parte preliminar de las 'Instituciones' de Marciano, Estudios en homenaje al Prof. F. Hernandez-Tejero, t. II, Madrid 1994.

Jońca M., Parricidium w prawie rzymskim, Lublin 2008.

Jörs P., Aelius 88, [w:] Real-Encyclopädie der classischen Altertumswissenschaft, red. A. Pauly, G. Wissowa, t. I. 1, Stuttgatr 1893.

Kołodko P., Ustawodawstwo rzymskie w sprawach karnych. Od ustawy XII tablic do dyktatury Sulli, Białystok 2012.

Krüger H., Römische Juristen und ihre Werke, [w:] Studi in onore Pietro Bonfante, t. II, Milano 1930.

Kunkel W., Die römsichen Juristen. Herkunft und soziale Stellung, Köln-Weimar-Wien 2001.

Lambertini R., Sull'esordio delle Istituzioni di Marciano, „Studia et Documenta Historiae et Iuris" 1995, nr 61.

Lenel O., Palingenesia Iuris Civilis, t. I-II, Lipsiae 1889.

Liebs D., Äelius Marcian. Ein Mittel des römischen Rechts in die hellenistiche Welt, "Zeitschrift der Savigny Stiftung für Rechtsgeschichte. Romanistische Abteilung" 2011, nr 128.

Litewski W., Jurysprudencja rzymska, Kraków 2000.

Longo G., lex Julia de vi publica e lex Julia de vi privata, [w:] Novissimo Digesto Italiano, t. IX, Torino 1961.

Longo G., lex Julia maiestatis, [w:] Novissimo Digesto Italiano, t. IX, Torino 1961.

Mantovani D., Il problema d'origine dell'accusa popolare: dalla "quaestio" unilaterale alla "quaestio" bilaterale, Padova 1989.

McGinn T.A.J., Prostitution, Sexuality, and the Law in Ancient Rome, New York 1998.

Misztal-Konecka J., Incestum w prawie rzymskim, Lublin 2007.

Mossakowski W., Rixa, czyżby starożytne chuligaństwo?, [w:] Ochrona bezpieczeństwa i porządku publicznego w starożytnym Rzymie, red. K. Amielańczyk, A. Dębiński, D. Słapek, Lublin 2010.

Nörr D., Causam mortis praebere, [w:] The Legal Mind. Essays for Tony Honoré, red. N. MacCormik, P. Birks, Oxford 1986.

Orestano R., Dal ius al fas. Rapporto fra diritto divino e umano in Roma dall'età primitiva all'età classica, „Bulletino dell'Istituto di Diritto Romano” 1939, nr 46.

Orestano R., Marciano Aelio, [w:] Novissimo Digesto Italiano, t. X, Torino 1964.

Pietrini S., L'insegnamento del diritto penale nei libri Institutionum, Napoli 2012.

Polara G., Marciano e l'elemento soggetivo del reato. Delinquintur aut proposito aut impetus aut casu, „Bulletino dell'Istituto di Diritto Romano” 1974, t. 77.

Rilinger R., Humiliores-Honestiores. Zu einer sozialen Dichotomie im Strafrecht der romischen Kaiserzeit, München 1988. 
Rizzelli G., Lex Iulia de adulteriis. Studi sulla disciplina di adulterium, lenocinium, stuprum, Bari 1997

de Robertis F.M., Sulla cronologia degli scritti dei giuristi classici, „Rivista Italiana per le Scienze Giuridiche" n.s. 1940, nr 15.

Rotondi G., Leges publice populi Romani. Elenco cronologico con una introduzione sull'attività legislativa dei comizi romani, Hildesheim 1966.

Rüpke J, Religion in Republican Rome. Rationalization and Ritual Change, Philadelphia 2012.

Rüpke J., Rationalizing Religious Practice. The Pontifical Calendar and the Law, [w:] Law and Religion in the Roman Republic, red. O. Tellegen-Couperus, Leiden 2012.

Schulz F., Storia della giurisprudenza romana, Firenze 1968.

Sini F., Bellum nefandum. Virgilio e il problema di "diritto internazonale antico", Sassari 1991.

Stolarek D., Adultera w świetle lex Iulia de adulteriis coërcendis, Lublin 2012.

Wenger L., Die Quellen des römischen Rechts, Wien 1953.

Wieacker F., Doppelexpemplare der Institutiones Florentins, Marcians und Ulpians, „Revue Internationale des Droits de l'Antiquite" 1949, nr 3.

Wieacker F., Römische Rechtgeschichte. Zweiter Abschnitt: Die Jurisprudenz vom frühen Prinzipat bis zum Ausgang der Antke, München 2006.

Wieacker F., Textstufen klassischer Juristen, Göttingen 1960. 